\title{
Suomen ja Baltian maitosektorien vertailu
}

\author{
Csaba Jansik ${ }^{1}$
}

Meijeriteollisuus on nopeasti globalisoitunut viimeisen vuosikymmenen aikana. Globalisaatio on ilmennyt kasvavassa meijerituotteiden ulkomaankaupassa sekä pääoman siirtymisessä rajojen yli. Prosessi on ollut hyvin nähtävissä Pohjoismaiden välillä ja koko Itämeren alueella. Suomen meijeriala on aktiivisesti osallistunut tähän prosessiin tekemällä sijoituksia ulkomaille ja viemällä meijerituotteita naapurimaiden markkinoille. Samanaikaisesti Suomi on ollut ulkomaisten sijoitusten ja muiden maiden meijeriviennin kohdemaana.

Tässä tutkimuksessa vertaillaan Suomen ja Baltian maiden tärkeimpiä rakennetta ja tehokkuutta kuvaavia indikaattoreita maidontuotannon, meijeriteollisuuden ja ulkomaankaupan saroilla. Hygieeninen taso, raaka-aineen laatu ja jalostusteknologia paranivat nopeasti Baltian maissa jo EU jäsenyyttä edeltävinä vuosina, mutta näiden liittyminen EU:hun vuonna 2004 nopeutti kehitystä entisestään. Kukin Baltian maa on vahvistanut maitoketjuaan tuottaen meijerituotteita reilusti yli oman tarpeensa. $\mathrm{Ne}$ ovat menestyksellisesti suunnanneet ylituotantoaan EU:n yhteisille markkinoille sekä kolmansiin maihin.

Vaikka kaikki neljä maata ovat vahvasti vientiorientoituneita ja tuottavuus on kasvanut jokaisen maan maitosektorilla, löytyy niiden välillä myös huomattavia rakenteellisia eroja. Erojen ja yhtenäisyyksien selvittämiseksi on käytetty erilaisia indikaattoreita kuten maidon keskituotos, maidontuotanto, maitotilojen rakenne, sekä meijeriteollisuuden osalta liikevaihto, voittoprosentti ja teollisuuden yritysrakenne. Eroavat maitotilarakenteet näkyvät erilaisissa raaka-ainehankinnan ratkaisumalleissa sekä maidontuotannosta jalostukseen käytettävän maidon osuuksissa.

EU:hun liittymisen jälkeen raakamaito ruvettiin kaikissa uusissa jäsenmaissa kauppaamaan rajojen yli, mikä aiheutti Baltian maissa maitohintojen tuntuvaa lähestymistä toistansa ja EU keskitasoa kohti. Viime vuosien lähenemisestä huolimatta on edelleen olemassa hintarako Suomen ja Baltian maitohintojen välillä.

Suomen maitosektorin näkökulmasta on tärkeä tarkastella vaikutuksia, joita Baltian maiden kehitys ja näiden liittyminen EU:hun on tuonut mukanaan. Suorat vaikutukset ovat havaittavissa kahdella pääalueella: (1) suorien ulkomaisten sijoitusten ja (2) maidon ja meijerituotteiden ulkomaankaupan kehityksessä.

(1) Suomen ulkomaan investoinnit ennen EU:n laajentumista rajoittuivat maitoketjusta meijeriteollisuuteen ja tulevien uusien jäsenmaiden joukosta lähinnä Viroon. Laajentumisen jälkeen kuitenkin sijoituksia on tehty myös alkutuotantoon, maitotiloihin, tosin pääkohdemaana on pysynyt näissäkin sijoituksissa Viro.

(2) Ennen itälaajentumista Suomessa kuultiin huolestuneita ääniä, jotka maalailivat Baltian halpojen meijerituotteiden ja muiden elintarvikkeiden tulvaa Suomen markkinoille. Viime kolmen vuoden toteutuneen ulkomaankaupan luvut eivät noita huolia todista. Tuonti Baltian maista on EU jäsenyyttä edeltävien vuosien tasoon nähden tosiaan kasvanut moninkertaiseksi, mutta se edustaa Suomen elintarvikemarkkinoissa ja jopa Suomen koko elintarviketuonnissa vain murto-osaa. Sitäkin voimakkaamman - vaikkakin välillisen - haasteen Baltian meijeriyritykset asettavat suomalaiselle maitosektorille kolmansien maiden markkinoilla. Etenkin liettualaiset meijerit ovat onnistuneet valloittamaan 1990-luvulla menetettyjä asemiaan takaisin Venäjän markkinoilla, jossa ne kilpailevat suomalaisten meijerituotteiden kanssa.

Asiasanat: Suomi, Baltian maat, maidontuotanto, meijeriteollisuus, ulkomaankauppa

\footnotetext{
${ }^{1}$ MTT Taloustutkimus, Luutnantintie 13,00410 Helsinki, csaba.jansik@mtt.fi
} 


\section{Johdanto}

Maitoketju on perinteisesti muodostanut merkittävimmän alan sekä Suomen että Baltian maiden maatalous- ja elintarvikesektoreissa. Tosin Suomessa lihateollisuuden liikevaihto on muutamana viime vuotena ylittänyt jo hieman meijeriteollisuuden vastaavat luvut, sen sijaan raaka-aineen tuotannon puolella on maidontuotanto pysynyt selvästi merkittävimpänä alana. Baltian maissa puolestaan koko maitoketju on ollut maatalous- ja elintarvikesektorin kiistattomasti suurin toimiala viimeisen kahdenkymmenen vuoden aikana.

Rakennekehityksen kannalta maat kulkivat varsin erilaisia teitä 1990 luvulla, vaikka muutokset kääntyivät sittemmin samansuuntaisiksi eli keskittymiin päin. Viime vuosikymmenen dramaattinen murrosvaihe Baltian meijerisektorilla kytkeytyy vahvasti poliittisiin ja taloudellisiin reformeihin. Siinä missä Suomen maitotilojen ja meijereiden rakenne sai kehittyä vuosikymmeniä askel askeleelta, muuttuivat ne 1990 luvun alkupuolella Baltian maissa rajusti ja kertaheitolla, jopa muutaman vuoden sisällä, taloudellisten reformien esim. maareformin ja yksityistämisen myötä.

\section{Maidontuotanto}

Nykyään neljän maan maidontuotanto voidaan tilarakenteeltaan luokitella kolmeen erityyppiseen ryhmään:

(1) suurten tilojen dominointi (Viro),

(2) keskikokoisten tilojen dominointi (Suomi),

(3) pienten tilojen dominointi (Latvia ja Liettua).

Suomen maitotilarakennetta dominoivat keskikokoiset tilat, 84 \% lypsylehmistä oli 10-49 lehmää käsittävillä tiloilla vuonna 2005. Samaan aikaan Virossa yli kaksi kolmasosaa lehmistä sijoittui suuriin, yli 100 lehmän tiloihin, kun taas Latviassa ja Liettuassa alle 10 lehmän tilat vastasivat $58 \%$ ja $69 \%$ koko lypsylehmäkannasta (Kuva 1).

Lähimenneisyyden kehitys selittää jokaisen maan maitotilarakenteen nykytilaa. Suomessa on siirrytty pientilavaltaisesta tilarakenteesta keskikokoisten tilojen dominointiin vuosikymmeniä jatkuneen asteittaisen prosessin tuloksena.
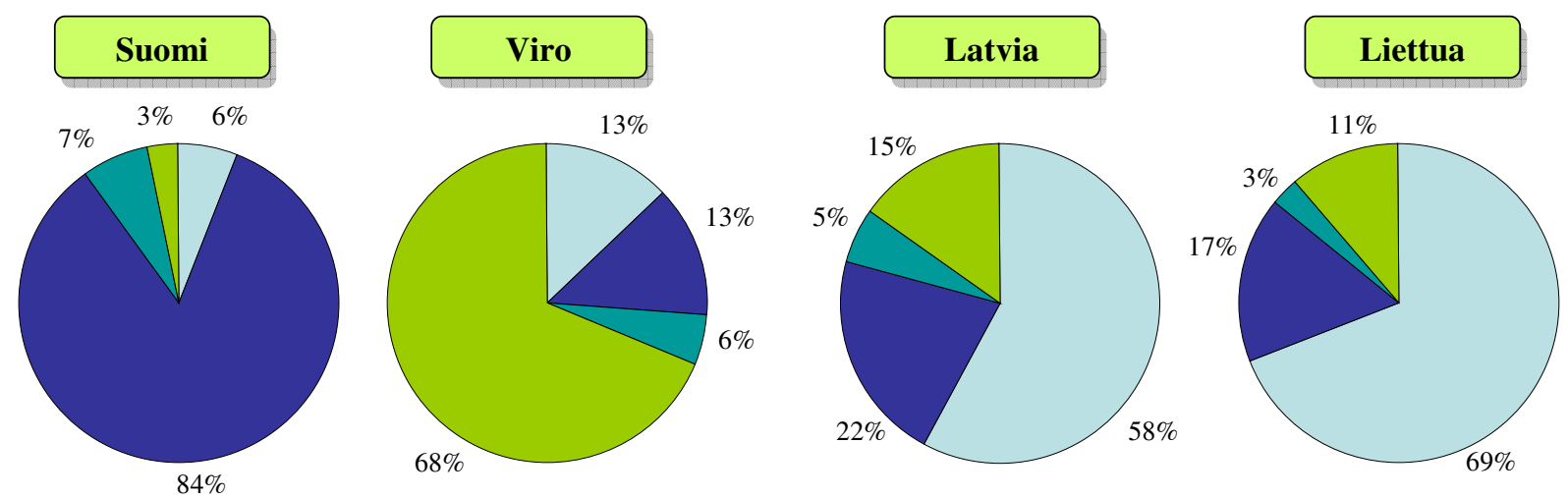

\begin{tabular}{|l|r|r|r|r|}
\hline \multirow{2}{*}{ Tilakokoluokka } & \multicolumn{4}{|c|}{ Lypsylehmien määrä (1000) } \\
\cline { 2 - 5 } & \multicolumn{1}{|c|}{ Suomi } & \multicolumn{1}{c|}{ Viro } & \multicolumn{1}{c|}{ Latvia } & \multicolumn{1}{c|}{ Liettua } \\
\hline alle 10 lehmää & 19,7 & 14,9 & 107,1 & 302,0 \\
\hline 10-49 lehmää & 267,5 & 15,2 & 39,7 & 74,3 \\
\hline 50-99 lehmää & 21,7 & 5,5 & 10,1 & 73,7 \\
\hline yli 100 lehmää* & 9,8 & 77,9 & 28,3 & 48,1 \\
\hline Yhteensä & 318,7 & 113,5 & 185,2 & 498,1 \\
\hline
\end{tabular}

Lähde: TIKE ja kansalliset tilastokeskukset. *Huom.: Suomen tapauksessa yli 75 lehmän tilat.

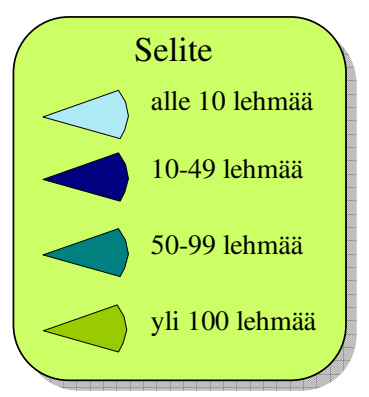

Kuva 1. Maidontuotannon rakenne Suomessa ja Baltian maissa 
Baltian maat perivät Neuvostoliiton ajalta suurtilavaltaisen rakenteen, 1980-90 luvun taitteessa yli kaksi kolmasosaa maidontuotannosta oli peräisin suurilta valtion tai osuuskuntien tiloilta. Virossa joitakin suurtiloja jaettiin, mutta suurimmaksi osaksi ne siirtyivät suoraan ja jakamattomina yksityiseen omistukseen. Latvian ja Liettuan maatilareformi 1990-luvun alkupuolella suosi pieniä perhetiloja ja muutokset johtivat suurten tilojen pirstoutumiseen. Valtaosa maitotiloista oli 1-2 lehmän pieniä tiloja, joista suurin osa harjoitti kotitarvetuotantoa ja vain alle puolet tuotti maitoa myydäkseen jalostusyrityksille.

Maidontuotannon määrä putosi kaikissa Baltian maissa 1990-luvun alkuvuosina 1980-luvun tason 50-60 \%:iin. Tilarakenteen muutosten ja yleisen maataloussektoria koskevan kriisin lisäksi pudotusta selittää irrottautuminen Neuvostoliiton sisäisistä markkinoista. Alkutuotannon lukuisat ongelmat vaikuttivat omalta osaltaan siihen, että Baltian maitosektori koki vaikeuksia sekä kotimaan- että vientimarkkinoilla. Uudet yksityiset maitotilat kärsivät pääoman puutteesta sekä kohoavien kustannusten ja alenevien myyntihintojen aiheuttamasta puristuksesta. Raakamaidon laatu huononi ja oli tiloittain erittäin vaihteleva.

Viimeisen kymmenen vuoden aikana kuitenkin alkutuotannon teknologia ja maidon laatu ovat parantuneet huomattavasti. Kansallisten ja EU tukien sekä jalostusyritysten avustamana tuhannet tilat ovat investoineet moderneihin lypsy- ja varastojärjestelmiin. EU:hun liittymiseen mennessä meijereiden ostamasta raaka-aineesta jo reilusti yli $90 \%$ oli ykkösluokan maitoa.

Maatalouskriisin ja reformien aikana jopa lehmien keskituotoskin laski huolestuttavasti. Kuitenkin markkinatilanteen ja maidontuotannon teknologian parantumisen sekä tuotantomäärien elpymisen ja tilojen keskikoon kasvun johdosta se kääntyi nousuun 1990-luvun puolessavälissä ja on kohonnut vuosi vuodelta.

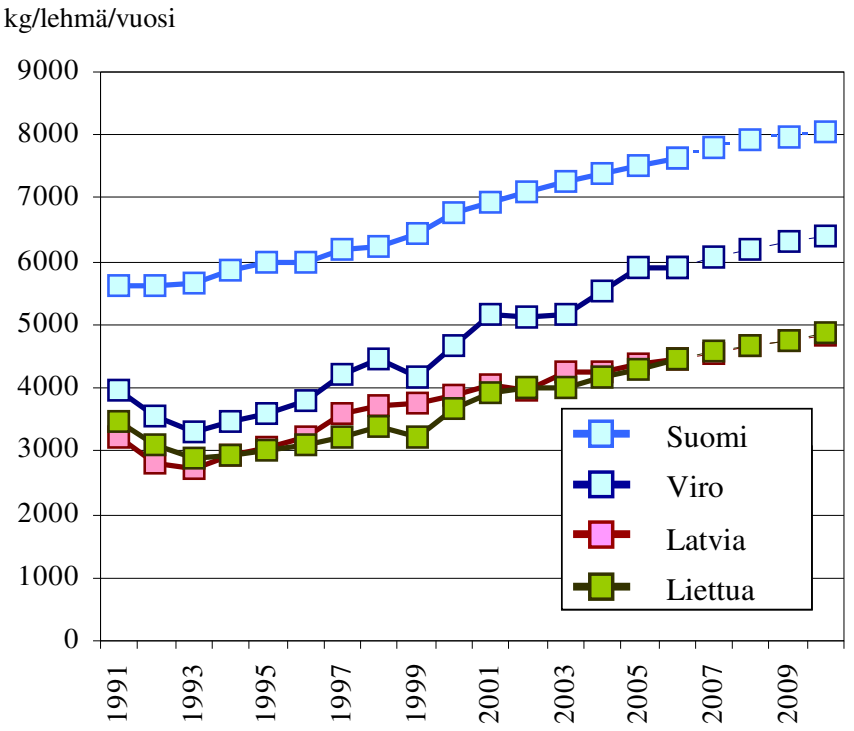

Kuva 2. Lehmien keskituotos Suomessa ja Baltian maissa vuosina 1991-2010.

Lähde: TIKE ja kansalliset tilastokeskukset.
Viime vuonna Latviassa ja Liettuassa keskituotos oli 4500 kilon tienoilla, Virossa lähes 6000 kiloa ja Suomessa se ylitti 7700 kiloa. Nousun odotetaan jatkuvan myös tulevaisuudessa, mutta maiden väliset erot pysynevät entisellään ainakin muutaman seuraavan vuoden aikana.

Maitotilat ovat keskittyneet yhä suurempiin yksikköihin sekä Suomessa että Baltian maissa. Tilojen kasvu on viime vuosina ollut varsin nopeaa etenkin Latviassa ja Liettuassa, jossa lähtökohta oli erittäin hajanainen tilarakenne. Vielä vuonna 1999 alle 10 lehmän tiloilla oli $87 \%$ lehmistä Liettuassa ja 73 \% Latviassa. Vuoteen 2005 mennessä näiden pienten tilojen osuus kutistui 69 \%:iin Liettuassa ja $58 \%$ :iin Latviassa. Vaurastuvat ja kasvavat keskikokoiset ja suuret tilat ottavat haltuun joka vuosi tuhansittain lopettavien 1-2 lehmän tilojen tuotanto-osuuksia.

\section{Maidonhankinta}

Meijereille myydyn maidon osuus koko maidontuotannosta vaihtelee merkittävästi neljän maan välillä. Suomessa se on ollut yli $95 \%$ 1990-luvun alusta lähtien, kun taas Virossa meijereiden osuus laski 55-70 \%:iin, Latviassa 35-45 \%:iin ja Liettuassa 55-65 \%:iin 1990-luvun puolivälin tienoilla. Meijereiden vastaanottama maito väheni kaikissa Baltian maissa Venäjän ruplan devalvaation jälkeisenä vuonna, 1999, mutta kääntyi nousuun 2000-luvun alussa. Muun maidonkäytön - tilakäyttö, rehukäyttö ja myynti paikallisilla markkinoilla - väheneminen viime vuosina on vahvasti kytköksessä tilarakenteen muutoksiin: pienten kotitarvetilojen häviämiseen ja keskikokoisten ja suurten tilojen kasvuun. Kolmesta Baltian maasta Viro lähentelee selkeästi länsimaista meijerien käyttöosuutta, joka selittyy isojen lehmätilojen suurella painoarvolla. 


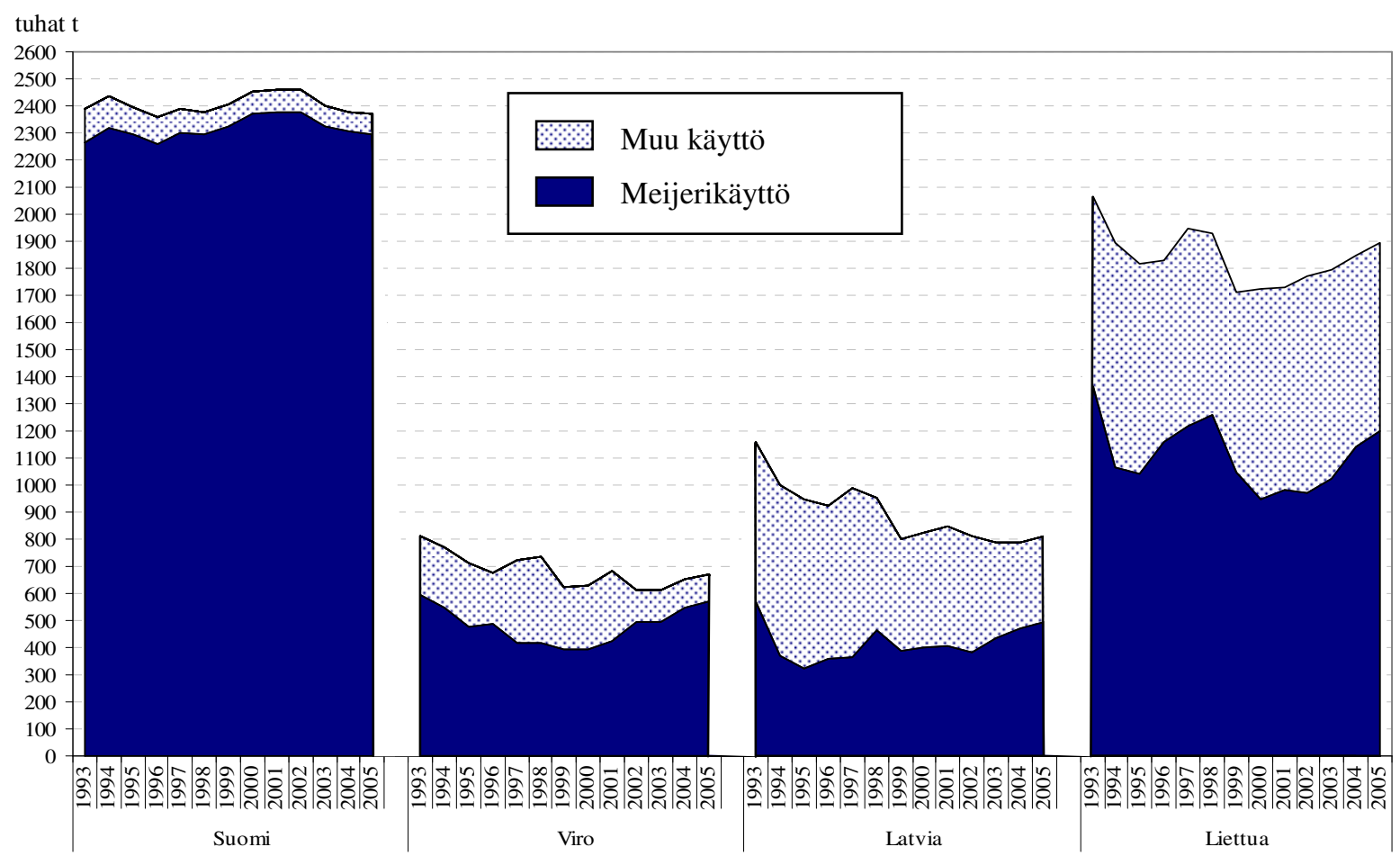

Kuva 3. Maidon tuotanto käyttötyypeittäin Suomessa ja Baltian maissa vuosina 1993-2005. Lähde: TIKE ja kansalliset tilastokeskukset.

Maidon meijerikäyttö on kautta Baltian noussut tasaisen nopeasti vuodesta 2002 lähtien. Nousukauden syynä on parantunut markkinatilanne koti- ja ulkomaan markkinoilla:

(1) Kotimaan markkinoilla 2000-luvulla vihdoin koettiin Baltian maiden BKT:n nopean kasvun vaikutuksia ruuan kulutuksessa. Tulojen kasvu on vaikuttanut positiivisesti myös maitotuotteiden kysyntään.

(2) Baltian meijeriyritykset pääsivät EU:n markkinoille jo 2000-luvun alkuvuosina, mutta 2004 liittyminen yhteisiin markkinoihin kasvatti vientimahdollisuuksia entisestään.

(3) Kolmansien maiden markkinoilla kysyntä on myös voimistunut viime vuosina.

Itälaajentuminen toi mukanaan mullistavia muutoksia Euroopan raakamaitomarkkinoilla. Uusissa jäsenmaissa vallitsevat maitohintatasot erosivat paitsi keskenään myös vanhojen jäsenmaiden hinnoista. Itälaajentuminen siis aiheutti raakamaidon välittömän kaupankäynnin yli rajojen.

Satoja tuhansia tonneja maitoa myytiin Keski-Euroopassa uusien jäsenmaiden kesken sekä uusista jäsenmaista esimerkiksi Italiaan ja Saksaan. Raakamaidon kaupan myötä hinnat ovat yhtäläistyneet ja entiset suuret erot ovat hupenemassa.

Sama ilmiö on havaittavissa Baltian maiden välisessä kaupassa ja hintasuhteiden kehityksessä. Hyvä markkinatilanne ja paranevat meijerialan suhdanteet nostivat maidon kysyntää Baltiassa. Meijerit aloittivat ankaran kilpailun raakamaidosta, jonka seurauksena maitoa hankittiin jo yli rajojen. Viime vuonna latvialaiset yritykset ostivat 55 tuhatta tonnia maitoa Virosta ja liettualaiset maidonjalostajat hankkivat niin ikään 130 tuhatta tonnia Latviasta. Raakamaidon ulkomaankauppa on vähentänyt maiden välillä alussa olleita hintaeroja sekä lähentänyt hintoja EU:n keskitasoon verrattuna.

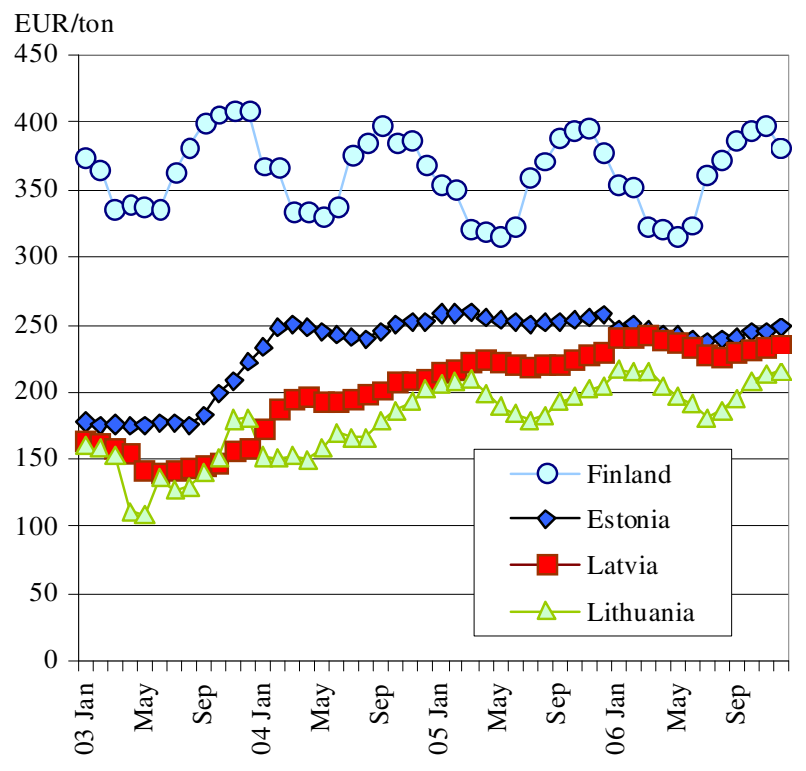

Kuva 4. Maidon kuukausihinnat Suomessa ja Baltian maissa vuosina 2003-2006.

Lähde: TIKE, Eesti Konjunktuurinstituut, Latvian Maatalouden Markkinatietokeskus, Liettuan Meijeriyhdistys. 
Kalliista maidon tuottajahinnasta huolimatta Suomen maitosektoria raakamaidon ulkomaankauppa ei koskenut. Toisaalta Suomen maidontuotanto on kattanut maan meijereiden kysynnän ja toisaalta meren yli kuljettaminen asettaa luonnollisen esteen raaka-aineen tuomiselle.

Maitotilarakenteen eroista johtuen meijerit joutuivat perustamaan erilaisia logistisia järjestelmiä maidonhankinnalle. Keskikokoisten ja suurten tilojen tuottama maitomäärä mahdollistaa sen että Suomessa ja Virossa valtaosa maidosta kuljetetaan suoraan tiloilta meijerille. Suorat kuljetukset tiloilta meijeriin eivät kuitenkaan olleet mahdollisia Latviassa ja Liettuassa, joissa on kymmeniä tuhansia pieniä tiloja. Meijerit ovat pystyttäneet taajamiin ja kyliin maidonkeruupisteitä, joihin pienet tilat toimittavat maitoaan ja joista yritysten kuljetusautot maidon puolestaan hakevat.

Meijerit Latviassa ja Liettuassa siirtävät maidonkeruun logistisia kustannuksia pientilojen maksettaviksi. Käytännössä tämä ilmenee alhaisempana maidon tuottajahintana. Esimerkiksi Liettuassa pienille tiloille maksettu hinta voi olla jopa 20-30 \% keskihintaa matalampi, kun taas suurille tiloille meijerit ovat valmiita maksamaan keskitasoa reilusti korkeamman hinnan. Suomessa hinnoittelun vaihtelu tilatyypeittäin on paljon vähäisempää, tosin alue- ja meijerikohtaisia eroja hinnoissa saattaa esiintyä.

\section{Meijeriteollisuus}

Meijeriteollisuuden rakenne on ollut melko vakiintunut Suomessa viimeisten 15-20 vuoden ajan. Osuusmeijereiden keskuudessa viime vuosikymmen on tosin tuonut runsaasti fuusioita ja rakenteellisia muutoksia, mutta ne eivät ole vaikuttaneet teollisuuden rakenteeseen. Suomen meijerialaa hallitsee osuustoimintapohjainen meijeri, Valio, jota seuraa Suomen oloissa keskikokoinen perheyritys Ingman Foods. Lisäksi toimialalla oli vuonna 2005 rekisteröity lähes 50 pienyritystä, jotka erikoistuvat tietyn tuoteryhmän, useimmiten tuorejuuston tai muiden tuoretuotteiden valmistukseen tai vaikka maidonhankintaan. Pienet yritykset vastasivat alle $10 \%$ meijeriteollisuuden liikevaihdosta vuonna 2005.

Suomesta poiketen Baltiassa meijeriteollisuuden rakennekehitys on ollut maiden itsenäistyttyä varsin myrskyisää. Neuvostoliiton ajan suuret jalostusyritykset pilkottiin useisiin eri tuotantolaitoksiin, jotka kaikki yksityistettiin erikseen. Virossa 11 suurta meijeriä jaettiin 36 pienempään laitokseen ja tuotantokapasiteetista $60 \%$ siirtyi maidontuottajien tai niiden osuuskuntien omistukseen, loput myytin muille kotimaisille sijoittajille. Maidontuottajia suosittiin myös Latviassa ja Liettuassa, joten 1990 luvun puolivälissä päättynyt yksityistäminen johti samankaltaiseen omistusrakenteeseen.

Vuosikymmenen loppupuolella markkinavaikeudet koettelivat meijereitä ankaralla kädellä ja kymmeniä yrityksiä kaatui viimeistään 1998 Venäjän kriisin aiheuttamassa konkurssiaallossa. Samalla alkoi voimakkaan keskittymisen, fuusioiden ja yritysostojen värittämä murroskausi. Keskittyneisyyden aste CR4 (concentration ratio 4, eli neljän johtavan yrityksen yhteenlaskettu markkinaosuus) kasvoi esimerkiksi Liettuassa $29 \%$ :sta 56 \%:iin vuosien 1994-1998 välisenä aikana. Keskittymisen lopputuloksena on nykypäivään mennessä joka maahan muodostunut kaksi tai kolme vahvaa meijeriyritystä. Loput ovat keskikokoisia tai pieniä usein pienempiin markkinasegmentteihin erikoistuneita maidonjalostajia.

Ensimmäiset ulkomaiset sijoittajat saapuivat Baltian meijeriteollisuuteen 1990-luvun lopulla. Suosituin kohdemaa on ollut Viro, jossa ulkomaisten omistusosuus pääomakannasta on lähes $40 \%$. Liettuassa se on nykyään $15 \%$ ja Latviassa $8 \%$. Luvut olivat EU:hun liittyessä jopa hieman korkeampia, mutta kotimaiset sijoittajat ostivat osan ulkomaisesta pääomasta takaisin Virossa ja Liettuassa. Viime vuosien transaktioiden myötä ulkomaisten sijoitusten osuus kasvoi myös Suomessa saavuttaen arviolta noin 5-6 \% pääomakannasta.

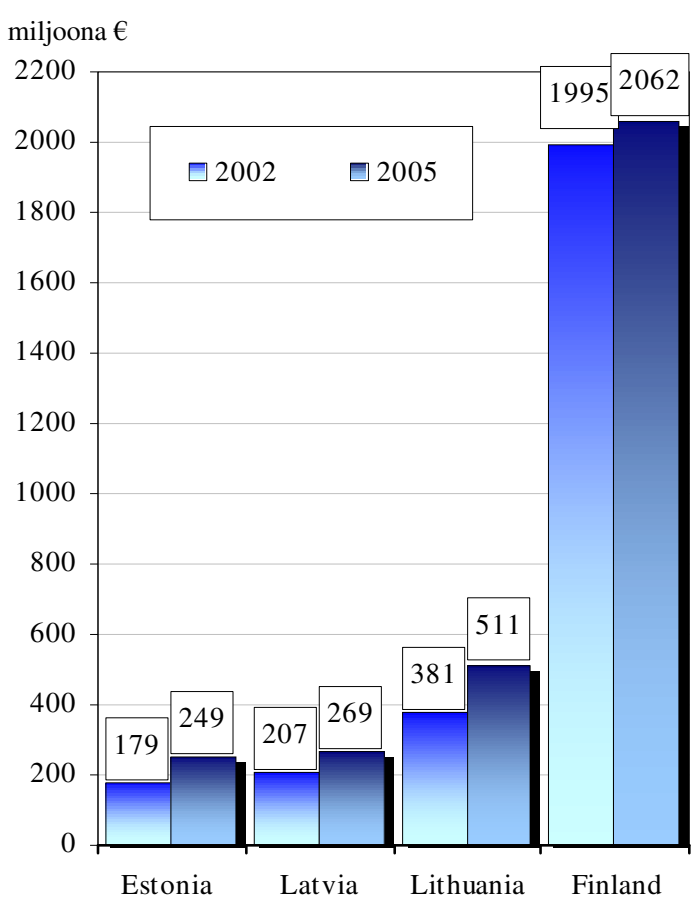

Kuva 5. Meijeriteollisuuden liikevaihto Suomessa ja Baltian maissa. Lähde: kansalliset tilastolaitokset. 
Kaikissa neljässä maassa meijeriteollisuuden liikevaihdot kasvoivat vuosien 2002 ja 2005 välillä. Kasvuvauhti kuitenkin eroaa Suomen ja Baltian välillä olennaisesti. Sillä aikaa kun Suomen myynti nousi 3,4 \% neljän vuoden aikana, kirjattiin reilusti nopeampaa kasvua Virossa (39\%), Latviassa (30 \%) ja Liettuassa (34\%). Maiden väliset kasvuerot ovat melko samanlaisia myös työntekijää kohti lasketun liikevaihdon osalta. Suomessa luku nousi $4 \%$ vuosien 2002 ja 2005 välillä, samalla kun se nousi Virossa $43 \%$, Latviassa $40 \%$ ja Liettuassa $26 \%$. Tietenkin Baltian maiden absoluuttiset tasot ovat Suomen vastaavia paljon pienempiä ja Baltian maissa meijeriteollisuus on yleensä vielä paljon työvoimavaltaisempaa.

Meijereiden voitot eroavat huomattavasti eri maiden ja varsinkin yritysten kesken. Koko meijerialan liikevaihtoon suhteutettu nettotulos jäi alle yhden prosentin Suomessa viimeisen kahden vuoden aikana. EU jäsenyys levensi tuloshaarukan Baltiassa. Meijeriteollisuuden keskimääräinen tulosprosentti sukelsi miinukselle vuosina 2004 ja 2005 Virossa. Tärkeimpänä syynä lienee ollut maidon äkillinen lähes $50 \%$ :n kallistuminen, joka johtui jäsenyyteen liittyneistä odotuksista ja tapahtui ennen EU jäsenyyttä vuoden 2003 lopussa. Virolaiset meijerit joutuivat maksamaan selkeästi koko Baltian korkeimmat raaka-ainehinnat EU jäsenyyden ensimmäisinä vuosina. Tämä verotti heidän voittoaan tuntuvasti. Tulosprosentti oli Latviassa 2-3\% ja Liettuassa vielä parempi, 3-4 \%. Kaikista maista löytyy muutama keskivertoa selvästi voitollisempi meijeri, toisaalta on useita nollavoittoa tuottavia tai etenkin Virossa - tappiollisia yrityksiä. Viime kuukausien suotuisa Euroopan ja maailman markkinoiden kehitys todennäköisesti parantaa kuitenkin meijereiden tuottavuutta joka maassa.

\section{Ulkomaankauppa}

Maidontuotanto sopii luontevasti pohjoisten maiden maataloustuotannon suurimmaksi sektoriksi. Kaikkien neljän maan maitosektorin tuotanto ylittää runsaasti kotimaisen kysynnän. Omavaraisuusaste pysyi myös kriisien - Baltian talousreformien, Suomen laman sekä Venäjän markkinavaikeuksien vuosina reilusti $100 \%$ :n yläpuolella.

Baltian maiden meijerialalla saatiin nopeasti aikaan kapasiteettien modernisointi ja tuotantorakenteet muutettiin perinteisistä massatuotteista korkeamman lisäarvon tuotteisiin kuten tuoretuotteet ja juustot. Baltian markkinoilla tulot ja brändättyjen meijerituotteiden kulutus nousivat käsi kädessä. Kotimaiset meijerit onnistuivat säilyttämään markkina-asemansa myös EU jäsenyyden alkuvuosina. Kun Keski-Euroopan uusissa jäsenmaissa meijerituotteiden tuonti kasvoi räjähdysmäisesti, oli kehitys Baltiassa maltillisempaa. Kotimaisen teollisuuden osuus pysyi Baltiassa korkealla, 86-92 \%:n välillä, jopa kasvaen hieman EU:ta edeltäviin vuosiin nähden esimerkiksi Virossa. Suomessa pitkään 93 \%:n yläpuolella pysynyt kotimaisten meijerituotteiden osuus laski $91 \%$ :iin vuosina 2004-2005.

Maidon ja meijerituotteiden ulkomaankaupan tase on ollut positiivinen, eli vienti on ylittänyt tuonnin kaikissa neljässä maassa 2000-luvulla. Viime vuosina Suomen tase on hieman kaventunut kasvavan tuonnin takia, kun taas Baltian maissa taseet ovat EU:n jäsenyysvuosina kasvaneet lähinnä viennin vauhdikkaan nousun siivittäminä. Maitosektorin ulkomaankauppa on reilusti ylijäämäinen ja kasvava, vaikka maiden välinen räjähdysmäisesti laajentunut raakamaidon ulkomaankauppa jätettäisiin laskelmien ulkopuolelle. Viennin rakenteessa on havaittavissa painopisteensiirto korkeammin jalostettujen ja erikoistuotteiden suuntaan.

Taulukko 1. Meijerituotteiden ulkomaankauppa Suomessa ja Baltian maissa (miljoona $€$ ).

\begin{tabular}{|c|c|c|c|c|c|c|c|c|c|c|c|c|}
\hline & \multicolumn{3}{|c|}{ Suomi } & \multicolumn{3}{|c|}{ Viro } & \multicolumn{3}{|c|}{ Latvia } & \multicolumn{3}{|c|}{ Liettua } \\
\hline & Tuonti & Vienti & Tase & Tuonti & Vienti & Tase & Tuonti & Vienti & Tase & Tuonti & Vienti & Tase \\
\hline 2000 & 90 & 195 & 105 & 12 & 38 & 26 & 6 & 17 & 11 & 9 & 103 & 94 \\
\hline 2001 & 93 & 259 & 166 & 15 & 49 & 34 & 12 & 21 & 9 & 37 & 148 & 111 \\
\hline 2002 & 97 & 274 & 177 & 16 & 60 & 44 & 17 & 23 & 6 & 36 & 169 & 132 \\
\hline 2003 & 102 & 275 & 173 & 20 & 63 & 42 & 19 & 20 & 1 & 14 & 152 & 138 \\
\hline 2004 & 115 & 266 & 151 & 39 & 58 & 20 & 20 & 22 & 2 & 11 & 152 & 141 \\
\hline 2005 & 136 & 275 & 139 & 21 & 76 & 55 & 23 & 40 & 18 & 13 & 220 & 207 \\
\hline 2006 & 150 & 298 & 147 & 16 & 83 & 67 & 31 & 63 & 32 & 35 & 246 & 211 \\
\hline
\end{tabular}

Lähde: Eurostatin ulkomaankauppatietokanta. 
Nopeasti kasvanut vienti nostaa kysymyksen, kuinka kilpailukykyinen näiden maiden meijeriala on kansainvälisessä vertailussa. Yksi mahdollinen indikaattori, jonka avulla saadaan vastaus, on Balassa indeksi (tai RCA indeksi, revealed comparative advantage). Balassa indeksit paljastavat jonkun maan tietyn tuotteen tai tuoteryhmän suhteellisen vientitehokkuuden. Indeksi lasketaan suhteuttamalla maan yhden tuoteryhmän tai tuotteen vientiosuutta maailmanmarkkinoilla maan kokonaisvientiosuuteen maailmanmarkkinoilla. Indeksin laskelmakaavio maalle $\mathrm{i}$ ja tuotteelle $\mathrm{j}$ on:

$$
R C A i j=100(X i j / X w j) /(X i t / X w t),
$$

jossa $X_{a b}$ on maan $a$ vienti ( $w=$ maailman) tuotteen $b$ osalta ( $t=$ kaikki tuotteet yhteensä). Mikäli indeksi on yli 1, maalla on komparatiivisia etuja kyseisen tuotteen osalta. Voi siis todeta, että maa erikoistuu kansainvälisessä kaupassa tämän tietyn tuotteen valmistamiseen ja viemiseen.

RCA indeksit kertovat kaikkien neljän maan meijerialalla olevan komparatiivisia etuja. Tosin indeksit myös paljastavat erikoistumisen asteen olevan maittain huomattavasti eri tasolla. Useamman vuoden aikajanalla RCA indeksit saattavat heilua tuntuvasti, mutta meijeriviennin komparatiivinen etu näyttää säilyvän sekä Suomessa että Baltiassa. Tason kehitykseen vaikuttaa selvästi maan koko viennin suuruus ja rakenne, eli kansantalouden muiden toimialojen viennin kehitys.

Taulukko 2. Suomen ja Baltian maiden meijerialan RCA (Balassa) indeksit.

\begin{tabular}{|l|r|r|r|r|}
\hline & Suomi & Viro & Latvia & Liettua \\
\hline 2003 & 1.3 & 3.4 & 3.6 & 5.5 \\
\hline 2005 & 1.5 & 3.3 & 3.9 & 5.7 \\
\hline
\end{tabular}

Lähde: FAO:n tilastoaineisto, omat laskelmat

\section{Johtopäätöksiä}

Maitoketju on syystä ollut jo vuosikymmeniä Suomen ja Baltian maiden maatalous- ja elintarvikesektorien lippulaiva. Ilmasto-olosuhteet sekä hyvät ja tuottoisat laidunalueet suorastaan determinoivat näiden maiden erikoistumisen maidontuotantoon. Pohjoisilla leveysasteilla jo lyhyestä kasvukaudesta johtuen olisikin ollut epärealistista erikoistua kasvituotteiden kuten viljan, vihannesten ja hedelmien tuotantoon.

RCA indeksit sekä historialliset vientitilastot todistavat sekä Suomen että Baltian maiden meijerialalla olevan komparatiivisia etuja kansainvälisessä kaupassa. Maitotilojen, meijeriyritysten ja omistuksen kannalta erirakenteiset maitoketjut ovat saavuttaneet omaan kokoonsa nähden vahvat asemat meijerituotteiden ulkomaankaupassa.

Toisaalta viennin rakennekin eroaa näiden maiden välillä tuoteryhmien ja kohdemaiden jakauman osalta. Rakenteeltaan sekä kooltaan Suomea lähimpänä on Liettuan meijerituotteiden vienti, joka kilpailee pitkälti samoilla tuoteryhmillä ja markkinoilla Suomen viennin kanssa. Kilpailukyvyn kannalta Liettuan maitoketjun heikoin lenkki on pirstoutunut maitotilarakenne. Ketjun kilpailukyvyn paranemisen ehtona on maitotilarakenteen kehityksen, ts. keskittymisen vauhti.

Globalisoituvassa ympäristössä lisääntyvän ulkomaankaupan ohella myös pääoma siirtyy maiden rajojen yli enenevissä määrin. On huomion arvoista, että ulkomaisten sijoittajien suurin mielenkiinto on kohdistunut juuri Viroon, pienimpään maitoketjuun neljästä maasta. Viro on saanut investointeja sekä maidontuotantoon että meijeriteollisuuteen useista eri maista. Huomattava määrä suoria ulkomaisia sijoituksia on tehty myös Suomen ja Liettuan meijeriteollisuuteen.

Suomen näkökulmasta FDI virrat nostavat esille kaksi vakavasti harkittavaa asiaa tulevaisuudessa. Toisaalta uudet sijoitukset ovat edelleen mahdollisia Baltian maissa. Etenkin Liettuan meijeriteollisuus tarjonnee kansainvälisesti merkittäviä yritysostomahdollisuuksia. Toisaalta Suomen suurimman meijeriyrityksen rooli Euroopan nopeasti keskittyvällä meijerialalla tai sen osallistuminen kansainvälistymiseen fuusioiden tai yritysostojen kautta on vielä avoinna.

\section{Kirjallisuus}

Balassa, B. 1965. Trade Liberalization and Revealed Comparative Advantage, The Manchester School of Economic and Social Studies 33, 99-123.

Niemi J. \& Ahlstedt J. 2007. Suomen maatalous ja maaseutuelinkeinot 2007. MTT Taloustutkimus, Helsinki. Saron T. 2006. Estonian Dairy Sector in 2005. Eesti Piimaliit, Tallinn, julkaisematon.

Pyykkönen P. \& Virolainen M. 2007. Osuusmeijerit myötätuulessa. Osuustoiminta 4/2007, s. 36-38. Kansallisten tilastokeskusten tietokannat. Aineistonkeruu Baltian maissa, sekä haastattelut Suomen, Viron, Latvian ja Liettuan virkailijoiden, maa- ja elintarviketalouden tutkijoiden ja meijerialan vaikuttajien keskuudessa. 